\title{
A Commentary on the History of Social Psychiatry and Psychotherapy in Twentieth-Century Germany, Holland and Great Britain
}

\author{
MICHAEL NEVE*
}

The detailed essays in this special issue of Medical History provide an opportunity for reflection on common themes as well as on differing medical and historical contexts, specifically examining the organization and practice of European social psychiatry, its various definitions, as well as the history of psychotherapy, in twentieth-century Germany, Holland and Great Britain. The chance has also arisen for one of the two guest editors to comment briefly on various other points that seem pertinent, by way of brief introduction. His fellow guest editor, Harry Oosterhuis, is the author of one essay and co-author of another.

One place to start is to situate the notion of "social psychiatry". Like so many key words and concepts in the history of medicine, there is very little in the phrase that did not involve a change of meaning in different times and different contexts of use. ${ }^{1}$ It may be true that some general characteristics were present in almost all uses of the expression, the most important being an emphasis on the familial and environmental origins of mental illness. To minister to such illness, illness in the "community", measures were taken to provide ambulatory care, that is to say care administered outside the asylum. The relations between social psychiatry and psychotherapy within this wider story are complex and with differing national pedigrees: in Holland, for example, psychotherapy was an offspring of psychoanalysis and the mental hygiene movement but this was not the case in either Britain or Germany. In general and especially in Britain, psychotherapies were seen by mainstream psychiatry in the first half of the twentieth-century as inadequate in one crucial regard, that of the long-term and chronically ill asylum patient. But as all these essays show, European biomedicine displayed enormous variations when the details are examined and any claim to an essentialist, all embracing definition of social psychiatry is very hard to establish. Indeed it would be historically speaking a mis-guided project to attempt such a thing, especially in the light of the independent developments within psychiatry and psychotherapy.

Take Germany, as examined in these pages by Schmiedebach, Priebe and Roelcke. Here, the meanings attached to social psychiatry were multiple. In the very early years of the century, social psychiatry both accepted an emphasis on the mental health of the whole population and an active programme as to how to prevent mental pathology increasing within that population. Strongly hereditarian, this psychiatry endorsed the prevention of unhealthy marriages and formed part of a wide-ranging battle against threats such as

\footnotetext{
* Michael Neve, PhD, The Wellcome Trust Centre for the History of Medicine at University College London, 24 Eversholt Street, London NW1 1AD, UK.

${ }^{1}$ An editorial collaboration between the Wellcome Trust Centre at UCL and the Lancet is currently
}

generating a very useful series based on medical keywords and their historical shifts in meaning. See, for example, Michael Neve, 'Neurosis', Lancet, 3 April 2004, 363 (9415): 1170, or Richard Barnett, 'Eugenics', Lancet, 22 May 2004, 363

(9422): 1742 . 


\section{Michael Neve}

syphilis and chronic alcoholism. If such a battle had to be fought well beyond the asylum, then so be it. If new kinds of medical examination had to include psychiatry (as happened in 1901) then so be it. The emergency that psychiatry had uncovered within the social order required an invigorated racial and mental hygiene and the surveillance and marginalization of epileptics and idiots and degenerates as well as the severely mentally ill. ${ }^{2}$ The asylum would be the place where the socially undesirable would be confined but the only setting in which these "types" could be identified would be in the wider social world. Not to vigorously police that wider world would be to risk various forms of racial "infection". And as this story escalates through the 1920s to the period of National Socialism, so too do the policies and interventions: sterilization, castration, euthanasia. It is of course important not to write the history of all pre-Nazi social psychiatry as a prelude to an inevitable historical outcome, but as in other aspects of German biomedicine at this time, Nazism was a culmination, an extremity. As a direct result (and very much bearing on the matter of words and their historical meanings mentioned earlier), Schmiedebach and Priebe show how the retrospective identification of the term "social psychiatry" with medical Nazism meant that after 1945 the expression was not used. When it was-eventually-resurrected in the 1960s and 1970s it had a very different and very deliberately humane, patient-centred meaning. There had to be (as it were) a new etymology, since the previous meaning carried with it an association with over a quarter of a million sufferers from mental illness and mental retardation now known to have been murdered. As Roelcke shows in his essay, the incorporation of psychotherapy in the German academic teaching world after the war was equally part of this new sense of meaning, seeking the rescuing of the "whole" patient from the bio-medical reductionism that had played such a terrifying part in genocide. But he also shows that this was a deliberately political act, not dependent on the acceptance or otherwise of the merits of psychotherapy by physicians themselves. A neurologist who had been an anti-Nazi used the post-war status that his actions gave him to build up an academic programme in Heidelberg in the face of strong opposition. The Heidelberg original then became the example for later German developments. Inescapably politicized, post-war German social psychiatry had a new medical rival—psychotherapy—with its own academic programme, training institutes and even its own guaranteed place inside the medical insurance system. Psychotherapy in Germany was built on the opportunities provided by the shamefulness of the bio-medical and social psychiatric past. By 1970, psychotherapy was an obligatory part of the medical teaching curriculum, a symbol of post-war reconstruction within medicine.

War thereby shaped both the institutional forms and the very meaning of the words used to describe certain medical practices and medical models. There could be no going back to the practices and the language of pre-war social psychiatry in Germany. In Britain, the place of the state within the political system and the place of medicine within the state were different, less centralized, even with the creation of a nationalized health service in 194648. Were there any equivalent developments to the German one in terms of social psychiatry

\footnotetext{
${ }^{2}$ Further connections can be made in an abundant literature on mental hygiene and race and eugenics in Germany. See Paul Weindling, Health, race and German politics between national unification and
}

Nazism, 1870-1945, Cambridge University Press, 1989, and Michael Burleigh, Death and deliverance: "euthanasia" in Germany c. 1900-1945, Cambridge University Press, 1994. 


\section{Commentary on the History of Social Psychiatry and Psychotherapy}

and psychotherapy? In a very telling detail in his essay here, Edgar Jones reminds us that by around 1950, there were very few consultant psychiatrists in London teaching hospitals, fewer psychotherapists and that Guy's Hospital Medical School, with a distinguished record in psychiatry, did not elect its first consultant psychiatrist until 1981. And yet recent historiography, mainly on the war neuroses and their treatment, has made it seem as if a fuller understanding of wartime psychopathology created opportunities for psychotherapeutic practice that continued after peace in 1945. In contrast to the post-war story after 1918, when psychotherapy was practised only briefly, if at all, remaining marginal in the 1920s and 1930s, the Second World War had an apparently deeper impact. ${ }^{3}$ Jones revises this account, examining the details of military psychiatry and Hollymoor Hospital at Northfield, Mill Hill Hospital and the York Clinic at Guy's in particular. He also looks at psychotherapy as practised in the field of battle. Did these military examples leave a coherent post-war legacy, specifically for psychotherapy? Leaving aside the absence of planned state genocide within the British polity and its military wing, was there a British equivalent to the restructuring of psychotherapeutics as was happening in Germany? Had the lessons of war and its traumas meant a sighting of a new "holistic" view of the patient, either public or private, less restricted by a mainstream psychiatry that was fundamentally organicist and reductionist?

The answer is a small yes and a big no. Firstly, both in the medical mind and in lay perceptions, psychotherapy meant Freudianism, with the followers of Freud and/or his successors, including Jung and Adler, sealed off in a private world of esoteric knowledge and unusually virulent squabbling. ${ }^{4}$ The hostility on the part of mainstream psychiatrists to even a diluted version of Freudian psychoanalysis has been well charted by historians: it was expensive, theoretically suspect and, in the admission of Freud himself, of no use in chronic psychotic cases. It is striking that in a British psychiatric landscape that from ... well, no one seems to be quite able to date the origins of the British version of "community care", but let us say from the early 1960s at the latest, psychoanalysis had no place in the mainstream profession. As Jones points out, the membership of the British Psycho-Analytic Society was 92 in 1939 and 175 by $1954 . .^{5}$ The war had indeed encouraged the expansion of academic departments of psychiatry and some - very small in number-psychotherapeutic appointments within them. Certain appointments-Aubrey Lewis as professor at the Maudsley might be one-and the growth of new specialisms, such as the occupational therapist, might be said to have a social psychiatric rationale. But as Jones again points out, if anyone was to come forward and display the right combination of empiricism and statistical skill in the post-war world, it was not to be the analysts (how could it be?), but the clinical psychologists-the Hans Eysencks of this world. One might also note the irony that the small but highly active coterie of psychoanalysts in London were of course

\footnotetext{
${ }^{3}$ Eric Rayner, The independent mind in British psychoanalysis, London, Free Association Books, 1990; Elaine Showalter, The female malady: women, madness, and English culture 1830-1980, London, Virago, 1987, especially ch. 7.

${ }^{4}$ On British scepticism regarding psychoanalysis, see, particularly, Trevor Turner, 'James Crichton-Browne and the anti-psychoanalysts', in
}

Hugh Freeman and German Berrios (eds), 150 years of British psychiatry, vol. II: The aftermath, London, Athlone Press,1996, pp. 144-55, and Dean Rapp, 'The early discovery of Freud by the British press: general interest and literary magazines', J. Hist. Behav. Sci., 1988, 24: 191-207.

${ }^{5}$ See Jones's essay in this issue, 'War and the practice of psychotherapy: the UK experience 1939-1960', p. 507. 


\section{Michael Neve}

mostly émigrés — refugees from totalitarianism and terror, including, just before his death, Freud himself. But unlike post-war Germany and despite some resistance there, this very psychoanalytic presence was not invited - or deliberately did not seek invitation- to the world of post-war medical rebuilding in Britain, the Britain that it inhabited. The shame of the recent past was irrelevant in Britain and thus the need to jettison some versions of psychiatry and now re-include some therapies that had been hunted down and expelled, absent.

Jones is not proposing that there were no psychotherapeutic developments: he notes the role played by psychiatric social workers and the work of individuals such as Maxwell Jones and his therapeutic community work at Belmont Hospital in Sutton among other examples. But not until the 1970s were psychodynamic ideas formally incorporated into medical training. I myself have recently had long conversations with the British psychiatrist Ronald Sandison, born in 1916 and thus now in his late eighties. A keen Jungian and a firm believer in group therapy, Sandison always used these approaches to follow up with NHS patients who had received either deep insulin coma therapy or electroconvulsive therapy or-a procedure much associated with Sandison personally-LSD. Sandison took the view that no proper cure could be expected of these physical treatments unless they were strictly used in conjunction with psychotherapy. Influenced by the work of T P Rees at Warlingham Park Hospital in Surrey, where Sandison worked after the war, group psychotherapy was used as part of these physical interventions. The hospital itself was seen as a larger therapeutic social world, complete with art therapy and therapeutic social clubs based on the ideas of Joshua Bierer, another refugee, in this case from the Steinhof mental hospital in Vienna. Sandison carried this eclecticism with him when he moved on to work at Powick Hospital near Worcester in 1951 and where he conducted his LSD therapies. ${ }^{6}$ His story demonstrates that some parts of the NHS psychiatric system did indeed develop in this way, using a combined approach of heroic therapies with immediate, and usually group-based, therapeutic follow up. But doctors who followed this route were of course always operating under financial stringency and under pressure for proven results. And other psychiatric programmes - most famously as directed by William Sargant at St Thomas's Hospital in London-went in a quite different, indeed mercilessly anti-psychotherapeutic, direction. For Sargant, no physical therapy was too heroic. Writing in 1961, Sargant stated that the psychotherapeutic and social treatment of psychoses and neuroses had been "fully explored" while physical treatments were in "relative infancy". In a world already familiar with deep insulin coma, malarial fever therapy, transorbital leucotomy and of course ECT, his remark bears some pondering. ${ }^{7}$

\footnotetext{
${ }^{6} \mathrm{R}$ A Sandison, 'Psychological aspects of the LSD treatment of the neuroses', J. Mental Sci., 1954, 100 (419): 508-15. On the more general history of the influence, such as it was, of psychotherapy on British psychiatry, the work of Malcolm Pines-himself a consultant psychotherapist at St George's Hospital—remains very useful. See his 'The development of the psychodynamic movement', in German Berrios and Hugh Freeman (eds), 150 years of British psychiatry 1841-1991, London, Gaskell, 1991, pp. 206-31. On the legal and consensual history of
}

mental health legislation in Britain, see Clive Unsworth, The politics of mental health legislation, Oxford, Clarendon Press, 1987, and Phil Fennell, Treatment without consent: law, psychiatry and the treatment of mentally disordered people since 1845, London and New York, Routledge, 1996.

${ }^{7}$ William Sargant, 'The treatment prognosis for functional psychoses in Great Britain', Am. J. Psychiatry, 1961, reprint held in the Sargant Papers, Archives and Manuscripts, Wellcome Library, London, PP/WWS Box 5 C.1/22. 


\section{Commentary on the History of Social Psychiatry and Psychotherapy}

In Britain we have therefore a mixed history, less politically overshadowed than the German experience and somehow more $a d$ hoc, even with the appearance of a socialized medical system. The equivalent Dutch history has some very striking lessons to teach the medical historian, mainly about continuity and consistency. As set out here by Oosterhuis and Hutschemaekers, the Dutch psychiatric world from the 1920s showed a very high level of continuity within social psychiatry and mental hygiene. There had, indeed has, been no radical de-institutionalization and from the 1960s onwards there was an emphasis on psychotherapy as well as institutional care. This held true even for long-term and hard to treat patients - a radical difference from our other two stories. Social psychiatry here meant care outside the asylum, beginning as a response to asylum overcrowding and then seeking answers to mental health problems in an age of economic depression in the 1930s. But Holland had its own considerable asylum population, at the same time as seeing an emphasis among many social psychiatrists on models of mental illness which emphasized a continuity model between sanity and madness (a model recently revived in Britain by the work of Richard Bentall). ${ }^{8}$

Post-war developments were complicated and not easy for outsiders to grasp fully. Attempts by leading Dutch psychohygienists to run an integrated care system, with social psychiatrists as intermediaries between asylum psychiatry and mental hygienists, had their ups and downs but-while drawing on American as well as British examples-a new ambulant mental health care system saw a particular Dutch form of emphasizing psychotherapy and education and environment in mental health. The creation of the Regional Institutes for Ambulatory Mental Health Care (RIAGGs) saw the social psychiatric approach more or less subordinated to psychotherapy, and proponents of social psychiatry feared that the seriously disturbed would not be properly cared for in the RIAGGs. These criticisms were met and by the mid-1980s the Dutch government had embarked on a programme of "socialization", forcing the integration at a regional level between RIAGGs, housing projects and institutional psychiatry. In the 1970s and developing from their origins in the 1940s and 1950s, there appeared an increasing number of Institutes for Multidisciplinary Psychotherapy; these in turn had to defend themselves against the newer RIAGGs on the grounds of a feared loss of autonomy and funding. Despite the complications, the striking Dutch example remains: that Dutch psychotherapeutic services have a very distinct history, including a rapid growth in ambulatory services as well as an independent profession. The most recent situation in Holland is in some ways the most interesting. As I understand Hutschemaekers' and Oosterhuis's essay, the RIAGGs have slowly become populated by health professionals rediscovering the merits of a stricter biomedical approach, with psychotherapists quitting the RIAGGs to go into private practice. So Dutch psychotherapists are now losing status, outmanoeuvered by a newly dominant biomedicine, legally answerable to psychologists, outside the RIAGG system and on the defensive. A remarkably unified history may actually be at the point of dividing up,

\footnotetext{
${ }^{8}$ Richard P Bentall, Madness explained: psychosis and human nature, London, Allen Lane, 2003. Bentall sees the legacy of Emil Kraepelin and his followers as the chief obstacle to a revived understanding of the continuity between normal and
}

abnormal mental states. The diagnostic labelling that has followed the Kraepelinian line has very few advantages and-through various forms of inept classification and naming of "diseases"-many disadvantages. 


\section{Michael Neve}

with psychotherapy no longer the "gold standard" it had been from the late 1960s until the mid-1980s. If this is true, then perhaps all the essays here do share one last final common theme: that no contenders in the various approaches to mental illness as professionally conceived-social psychiatric, institutional and asylum based, psychotherapeutic, even psychoanalytic - have a guaranteed presence on the medical stage. Political events, social events, state expenditure and the need for savings, the growth of psychopharmacology, lay involvement followed by lay indifference, war, peace: all play their determining part. And in doing so, they change both the history of words and the history of practices. 